\title{
NOTES
}

\section{NON-COMMUNIST AFFIDAVITS BY UNION "OFFICERS" UNDER TAFT-HARTLEY SECTION 9(h): A "CONSTITUTIONAL" VERSUS A "FUNCTIONAL" TEST*}

Bx denying the administrative channels of the NLRB to unions whose officers have not filed non-Communist affidavits, section $9(\mathrm{~h})$ of the Labor Management Relations Act ${ }^{1}$ attempts to influence unions to reject Communist control.2 Noncomplying unions ${ }^{3}$ may not participate in representation pro-

*NLRB v. Coca-Cola Bottling Co. of Louisville, 350 U.S. 264 (1956), reversing 219 F.2d 441 (6th Cir. 1955); Goodman Mfg. Co. v. NLRB, 227 F.2d 465 (7th Cir. 1955), dismissed by consent, 351 U.S. 901 (1956), opinion withdrawn, judgment aff'd on nezi apinion, 234 F.2d 775 (7th Cir.), cert. denied, 352 U.S. 872 (1956).

1. Section $9(\mathrm{~h}), 61$ Stat. 146 (1947), as amended, 29 U.S.C. $\$ 159(\mathrm{~h})$ (1952), provides:

"No investigation shall be made by the Board of any question affecting commerce concerning the representation of employees, raised by a labor organization ... and no complaint shall be issued pursuant to a charge [of an unfair labor practice] made by a labor organization ... unless there is on file with the Board an affidavit executed contemporaneously or within the preceding twelve-month period by each officer of such labor organization and the officers of any national or international labor arganization of which it is an affiliate or constituent unit that he is not a member of the Communist Party or affiliated with such party, and that he does not believe in, and is not a member of or supports any organization that believes in or teaches, the overthrow of the United States Government by force or by any illegal or unconstitutional methods. The provisions of section 35A of the Criminal Code shall be applicable in respect to such affidavits."

Criminal Code $\S 35 \mathrm{~A}$ is the Federal False Information Act, 62 STAr. 749 (1948), 18 U.S.C. $\$ 1001$ (1952). It provides for a fine of not more than $\$ 10,000$ or imprisonment for not more than 5 years or both.

The constitutionality of $\S 9(\mathrm{~h})$ was upheld in American Communications Ass'n, CIO v. Douds, 339 U.S. 382 (1950). See 51 Colun. L. Rev. 130 (1951) ; 35 Minn. L. Rev. 200 (1951); 99 U. PA. L. Rev, 409 (1950). On $\S 9(\mathrm{~h})$ generally, see Comment, The NonCommuntist Affidavit Requirement of the Taft-Hartley Act, 18 U. CHI. L. Rev. 783 (1951); Kearns, Non-Communist Affidavits Under the Taft-Hartley Act, 37 Geo. L.J. 297 (1949).

2. The consequences of noncompliance are designed to induce dismissal of officers refusing to file. See Leedom v. International Union of Mine Workers, 352 U.S. 145 (1956); NLRB v. Highland Park Mfg. Co., 341 U.S. 322, 325 (1951) ; American Communications Ass'n, CIO v. Douds, 339 U.S. 382, 387-90, 393, 400, 412, 418-19 (1950) (concurring opinion of Frankfurter, J.); id. at 434 (concurring, dissenting opinion of Jackson, J.). See also 93 Cong. Rec. 3519, 4880, 7492 (1947) ; H.R. REP. No. 245, 80th Cong., 1st Sess. 38-39 (1947). Some of these legislative proceedings were held when the area covered by $\S 9(\mathrm{~h})$ was embodied in $\S 9(f)(6)$ of the House bill under which no union could be certified if it had Communist officers. Section $9(\mathrm{~h})$ was substituted by a Senate-House conference com- 
ceedings, ${ }^{4}$ nor will unfair labor practice complaints be issued on their behalf." Further, the act, as interpreted, allows the question of a union's compliance with the section to be raised by employers and rival unions in unfair labor practice and representation proceedings ${ }^{6}$ as well as in independent NLRB investigations. $^{7}$

Although the consequences of noncompliance are clear, the act did not specify the exact meaning of the term "officer." Until recently, authorities differed sharply as to which members of the union's hierarchy were officers under the act and thus obliged to file affidavits. Most courts did not question the Board's

mittee to avoid delays in certifying unions as bargaining agents. 93 CoNG. REc. 6361, 6375, 6447, 6860 (1947) ; Hearings Before the Subcommittee on the Study of Conmmunist Domination of Unions and National Security of the Senate Conmittee of Labor and Public Welfare, 82d Cong., 2d Sess. 91 (1952).

3. Noncompliance may also result from failure to file information required by $\$ \$ 9(f)$ and $9(\mathrm{~g}) .61$ STAT. 145 (1947), 29 U.S.C. $\$ \$ 159(\mathfrak{f}),(\mathrm{g})$ (1952). The former requires a union to file with the Secretary of Labor detailed reports about its constitution, by-laws, conditions of membership, officers and financial status. Financial statements must also be furnished to all union members. Section $9(\mathrm{~g})$ requires a yearly supplement to $\$ 9(\mathrm{f})$. See 13 NLRB ANn. REP. 21-22 (1948).

Both national or international organizations as well as local unions must comply. Northern Virginia Broadcasters, Inc., 75 N.L.R.B. 11 (1947) ; Rules and Regulations of the NLRB \& 102.13(b) (Series 6, 1952). Since NLRB v. Highland Park Mfg. Co., 341 U.S. 322 (1951), federation level officers must also file affidavits before any "level" can use the Board. But a geographical subdivision of a union, such as a "region" or "district," need not comply if not itself an independent "entity." Grand Central Aircraft Co., 106 N.L.R.B. 358 (1953) ; Newport News Children's Dress Co., 89 N.L.R.B. 442 (1950).

4. 19 NLRB ANN. Rep. 9 (1954); 15 id. 19 (1950); 14 id. 13, 15 (1949); 13 id. 21-22 (1948).

A noncomplying union is denied a place on the ballot if another union or the employer files the representation petition. Sigmund Cohn Mfg. Co., 75 N.L.R.B. 177 (1947) ; Hermann Lowenstein, Inc., 75 N.L.R.B. 377 (1947) ; see 22 L.R.R.M. 36 (1947). Not being on the ballot, the noncomplying union cannot object to an election. $\mathrm{H}$. O. Canfield $\mathrm{Co}$., 80 N.L.R.B. 1027 (1948) ; Times Square Stores Corp., 79 N.L.R.B. 361 (1948). But a motion after a representation hearing to be placed on the ballot has been upheld if the union shows "adequate interest," see note 42 infra, prior to the hearing although compliance was effected after it. Associated Business Serv., 107 N.L.R.B. 219 (1953). Furthermore, a noncomplying union with a contractual interest is allowed to intervene in a hearing and raise its contract with the employer to bar a representation election. Congoleum-Nairn, Inc., 115 N.L.R.B. 1202 (1956) ; Northern Indiana Pub. Serv. Co., 91 N.L.R.B. 172 (1950); Bush Woolen Mills, Inc., 76 N.L.R.B. 618 (1948).

5. See $\S \dot{9}(h)$, supra note 1 . See also 19 NLRB ANN. Rep. 9 (1954); 15 id. 19 $(1950) ; 13$ id. 47 (1948). A union shop agreement entered into by a noncomplying union is invalid. Section 8(a) (3), 65 Stat. 601 (1951), 29 U.S.C. § 158(a) (3) (1952). See 19 NLRB ANN. REP. 9 (1954); 16 id. 40 (1951).

6. See note 44 infra.

7. While initially the Board administratively determines compliance matters on its own information, the agency permits parties to submit evidence that a union is not in full compliance. The Board may then conduct a second investigation. Coca-Cola Bottling Co. of Louisville, 108 N.L.R.B. 490, $491-92$ (1954) ; Metropolitan Life Ins. Co., 90 N.L.R.B. 935 (1950).

8. See text of $\S 9(\mathrm{~h})$, supra note 1 . 
position that section $9(\mathrm{~h})$ required filing only by persons labelled officers in union constitutions. ${ }^{9}$ While agreeing that the act demanded a "constitutional" test, the Seventh Circuit in Goodman $M f g$. Co. $v . N L R B^{10}$ sought to broaden the inquiry. It permitted litigation of whether compliance was required by individuals who, although not designated officers, held offices described in the constitution. The Court of Appeals for the Sixth Circuit, however, broke with the Board's test entirely. In NLRB v. Coca-Cola Bottling Co. of Louisville, ${ }^{11}$ it held that the meaning of officer was to be decided not solely by constitutional terminology, but rather by an appraisal of an individual's union activities, influence and duties. Thus, the court instructed the Board to hear testimony in an unfair labor practice proceeding on whether a noncomplying $\mathrm{CIO}$ regional director, not labelled an officer in the federation's constitution, was actually an officer because of his influential position.

On certiorari, the Supreme Court rejected the Sixth Circuit's "functional" test and sanctioned the Board's "constitutional" test. ${ }^{12}$ The Court considered the term officer applicable only to "those who hold defined offices," not "the boys in the back room" nor other members of a union's "invisible government." Section $9(\mathrm{~h})$ itself did not define officers, the Court noted, but its ordinary meaning was met by the constitutional test. And if viewed as a technical term of labor relations, the Board's definition, if reasonable, should be determinative because of that agency's expertise. ${ }^{13}$

An attempt to resolve conflicting decisions in the troubled area of compliance litigation, the Coca-Cola case has achieved its objective only partially. In its leading opinion after the Coca-Cola case, Desaulmiers and Co., ${ }^{14}$ the NLRB reaffirmed its narrow view of the constitutional test. But interpreting the Supreme Court decision more liberally, the Seventh Circuit, requested to reexamine its broad view of the constitutional test, ${ }^{15}$ reiterated its earlier position that the term officer includes individuals whose offices the union constitution described. ${ }^{16}$ The Seventh Circuit's interpretation seems preferable to the Board's. It is not unreasonable to assume that persons whose positions are described in the union constitution are of sufficient importance to be designated

9. The Board defines "officer" as: "[A]ny person occupying a position identified as an office in the constitution of the labor organization. ..." Rules and Regulations of the NLRB $\S 102.13$ (b) (3) (Series 6, 1952). This test has been utilized by the Board since the passage of the Labor Management Relations Act, 61 STAT. 136 (1947), 29 U.S.C. \$\$ $141-88$ (1952). Although the earlier language differs from Series 6, supra, the meaning is the same. See Rules and Regulations of the NLRB $\$ 203.13$ (b) (Series 5, 1947).

10. 227 F.2d 465 (7th Cir. 1955), dismissed by consent, 351 U.S. 901 (1956), opinion withdrawn, judgment aff'd on new opinion, 234 F.2d 775 (7th Cir.), cert. denied, 352 U.S. 872 (1956).

11. 219 F.2d 441 (6th Cir. 1955), rev'd, 350 U.S. 264 (1956).

12. NLRB v. Coca-Cola Bottling Co. of Louisville, 350 U.S. 264, 268-69 (1956).

13. Id. at $268-69$.

14. 115 N.L.R.B. 1025 (1956).

15. Goodman Mfg. Co. v. NLRB, 234 F.2d 775 (7th Cir.), cert. denied, 352 U.S. 872 (1956).

16. Id. at 779. The court indicated that the Supreme Court in Coca-Cola had not in- 
officers under section $9(\mathrm{~h}) .{ }^{17}$ Nor does this broader approach raise any problems of difficult interpretation or proof for the Board or unions; in every instance a constitutional source is available on which to hinge decisions that compliance is necessary. ${ }^{18}$

Permitting unions themselves to determine which individuals need comply, neither the Supreme Court nor the Seventh Circuit decision meets the policies underlying section $9(\mathrm{~h})$. Although somewhat broader than the Coca-Cola test, the Goodman interpretation apparently requires not only a listing of the office in the constitution, but a description of its powers and duties. ${ }^{19}$ In requiring unions to file non-Communist affidavits, Congress was seeking to eradicate Communist influences from each and every level of union leadership. ${ }^{20}$ Although

tended to give an exclusive definition of the word officer. Alternatively, the Seventh Circuit felt that its interpretation fell within the definition. Id. at 778 .

The Board's definition of an officer, see note 9 supra, would theoretically authorize the Goodman test. Actually, however, the Board has interpreted its own definition more restrictively. Desaulniers and Co., 115 N.L.R.B. 1025 (1956). Both the Board's view and the broader Seventh Circuit test find support in the language of $\mathrm{Coca}$-Cola; after quoting the Board's definition, the Court also declared: "'[O]fficers' normally means those who hold defined offices." NLRB v. Coca-Cola Bottling Co. of Louisville, 350 U.S. 264, 269 (1956).

17. The importance of the district-secretaries whose noncompliance was challenged in Goodman is revealed by the powers of the Executive Board on which they sat and voted. This group had authority relating "to every facet of management and control of the International Union as well as its affiliated District Councils and Local Unions. Its power and authority [encompassed] both the policy making and administrative fields." 234 F.2d at 779. This is generally true of all international unions. BARBASH, TyE PrActice of Unionism 63-64 (1956) ; Peterson, American Labor Unions 64-65 (1945) (hereinafter cited as PeTERSon). In one NLRB case the charge that executive board members were "officers" because of the nature of their duties and responsibilities was rejected on the basis of the Board's constitutional test. General Shoe Corp., 109 N.L.R.B. 618 (1954) (of eleven executive board members, only two were constitutional officers).

18. Recently an NLRB trial examiner followed the Goodman view of the "constitutional" test. In Kohler Co., Case No. 13-CA-1780, N.Y. Times, Oct. 17, 1956, p. 42, col. 6, the examiner interpreted the Board's constitutional test to permit litigation of whether an individual held a position defined as an office in the union constitution. He then defined an office as any position the duties of which were described in the constitution. Desaulniers and Co., 115 N.L.R.B. 1025 (1956), see text accompanying note 14 supra, was distinguished on the ground that the employer challenging compliance there had not alleged the noncomplying individual to be an officer within the constitutional test.

Relying on Desaulmiers, the Board overruled the trial examiner. Kohler Co., 117 N.L. R.B. No. 42 (Feb. 6, 1957). This result was foreseeable. Another trial examiner, in Illinois Malleable Co., Case No. 13-CA-1866 (1956), had recently denied a motion, based on the intermediate order in Kohler, to litigate the officer status of UAW trustees, the personnel held required to file in the Kohler intermediate order. The Board refused to review this ruling when the employer attempted a direct appeal. (Oct. 22, 1956). See Brief for General Counsel on review of Intermediate Order, Kohler Co., supra, Nov. 8, 1956.

19. 234 F.2d at 778-79.

20. See NIRB v. Highland Park Mfg. Co., 341 U.S. 322, 325 (1951.); American Communications Ass'n, CIO v. Douds, 339 U.S. 382, 388, 393 (1950); id. at 418-19 (con- 
Congress used the term officer to designate persons required to file, it evidenced no intent to qualify the term as the constitutional test does; on the contrary, debates on the section used the term "leader" interchangeably with "officer."21 Anchored to purely verbalistic distinctions and operating without regard to a union's actual power structure, ${ }^{22}$ any constitutional standard is of limited effectiveness in controlling Communist influences in labor. Since the act does not require uniformity, union constitutions may and do differ: like positions are present in some constitutions, absent in others. ${ }^{23}$ As a result, constitutional offices seldom reflect internal control relationships accurately. The practical exercise of power, indicated by actual duties and functions, may occur at levels below those of constitutional offices. ${ }^{24}$ Structurally complex, modern labor or-

curring opinion of Frankfurter, J.) ; NLRB v. Postex Cotton Mills, Inc., 181 F.2d 919, 920 (5th Cir. 1950). For congressional debates on removal of Communist leaders, see note 21 infra.

21. 93 Cong. Rec. $3626,3627,6382$ (1947).

22. "It is the informal power relationships that are decisive, and these ... are shaped by tradition, values, and practical considerations of available funds, agents and knowledge."” Kovner, quoted in Rosen \& Rosen, The Union Memrer Speaks 14 (1955).

"In reality, of course, [national] control can stem from a variety of sources in addition to the constitution (agreements, traditions, etc.)." Shister, Trade-Union Government: A Formal Analysis, 60 Q.J. Econ. 78, 110 n.4 (1945).

23. Of 57 national and international labor union constitutions on file in the Industrial Relations Section of the Princeton University Library, 29 briefly mentioned the duties of organizers, 18 described this position fully. Although all such unions employ organizers, 10 did not list the position in their constitutions. Of 34 constitutions which established a union publication 4 did not provide for an editor, 9 listed the executive board as controlling the publication, 8 the president, 1 the secretary-treasurer. Ten provided for appointment of an editor and two designated the editor as a named officer. A sampling of 13 constitutions revealed trustees listed as named officers in 4 . Their duties were described in 5 , while in the remaining 4 no mention of this position was made.

For the divergence in the constitutions of national unions in different industries, see Shister, supra note 22 , at 78, 82-89. The varying types of business organizations in different industries aid in molding union structures. Barbash, ThE Practice of UNIONISM 94 (1956).

24. Congressional hearings on Communist influence in unions support this view. Continuing beyond a union's creation, the powers of organizers on both the national and local level are extensive. They include participation in collective bargaining, handling grievances and generally servicing the organized locals. Hearings Before the House Committee on Un-American Activities Regarding Communist Inflitration of Labor Unions (Local 601 UERMIW A, Pittsburgh, Pa.), 81st Cong., 1st Sess. 341, 834-35, 860, 3530 (1949) ; Hearings Before the House Committee on Un-American Activities Regarding Communist Activitics in the Chicago Area (UERIIWA), 82d Cong., 2d Sess. 3624 (1952). See also Peterson 67-68. Organizers may be among the top leadership in a district of an international union. Hearings Before the Subcommittee on the Study of Subversive Influence in the UERIIVA of the Senate Committee on the Judiciary, 83d Cong., 2d Sess. 59 (1952). The duties of UE organizers are described in the UE Constitution, Art. 12. These personnel might therefore be susceptible to the Goodman test; but such description is not usual in other constitutions. See note 23 supra. Moreover, such nonconstitutional positions as those of chief stewards or bargaining and grievance committee chairmen are of substantial importance in day-to-day union activities. Chief stewards may even be the most 
ganizations can operate only through important delegations of authority to intermediate executive personnel. ${ }^{25}$ For example, business agents, full time union employees usually appointed and sometimes not constitutional officers, ${ }^{21}$ may hold important positions. ${ }^{27}$ The influence of organizers, whose positions are usually listed but not described in an international's constitution and not mentioned at all in local constitutions, ${ }^{28}$ is extensive and continuing. ${ }^{20}$ Similar-

important leaders in a plant. Hearings Regarding Communist Infiltration of Labor Unions, supra, 582-83, 588; Hearings Regarding Communist Activities in the Chicago Area, supra, 3624, 3721; Peterson 80; Sayles \& Strauss, The Local Union 40-41 (1953). See also Barbash, Labor Unions In Action 113 (1948).

25. See Brief for CIO and AFL as Amicus Curiae, pp. 4-10, NLRB v. Coca-Cola Bottling Co. of Louisville, 350 U.S. 264 (1956). PETERSon 41-55 (federations), 57-73 (internationals), 76-83 (locals).

In addition to the control vested in the president, executive secretary, general secretarytreasurer and the executive board comprised of the three mentioned officers and twentytwo vice-presidents, the International Ladies' Garment Workers Union places authority in local unions, joint boards, regional departments and district councils. Joint Boards possess full staffs and elect their own officers. They often represent craft locals in contract negotiation, organizational activities and the grievance-arbitration process. Regional departments, headed by an international vice-president and a manager, are composed of locals in outlying areas. Where there are scattered craft shops doing different types of work, district councils, with appointed heads, are formed "to stimulate organization and education in the area covered." Education DeP'T of THE InTERnational Ladies' GaRMent Workers Union, Structure and Functioning of the ILGWU 13-20 (1955). Trade locals handle their own affairs and craft units under district councils "usually negotiate their own agreements with the aid of the general organizer." Ibid.

26. Of 30 local union constitutions (28 of which were contained in the constitution of their national or international) on file in the Industrial Relations Section of the Princeton University Library, business agents were named officers in but 2 . Two provided for the election of business agents, 3 others only listed this position, and in the remaining 23 no mention was made.

27. Business agents play a key role in collective bargaining, organizing, discipline enforcement of agreements and grievance procedure. BARBASH, THE PRACTICE OF UNIONISM 191 (1956); Peterson 79-80; Rosen \& Rosen, The Union Member Speaks 14 (1955); Sayles \& Strauss, The Local Union 9 (1953) ; Weber, Union Decision-Making in Colrectrve Bargaining 160, 163 (1951). See also the model local constitution contained in the constitution of Upholsterers' International Union of North American (1953) ; Mcarings Regarding Communist Infiltration of Labor Unions, supra note 24, at 3534; Hcarings Regarding Communist Activities in the Chicago Area, supra note 24, at 3651 . Since business agents apparently are appointed only on the local or district level, their power may depend in large part on the form collective bargaining takes in different industries. Presumably, they are more powerful where collective bargaining is conducted on the local union level, as in the construction industry. See Pierson, The Government of Trade Unions, 1 Ind. ANd LAB. Rez. REv. 593, 605 (1948).

28. Only 18 of the 57 constitutions examined, see note 23 supra, described the duties of organizers, while 29 mentioned the position without any description of duties. Of the 30 local constitutions, see note 26 supra, 3 mentioned organizers and only 1 listed the post as an officer's position.

29. See note 24 supra.

"In the maintenance and distribution of power the role of the international representative is of some significance. It is his task to aid the locals in organizing, nego- 
ly, a regional director of the CIO, the union official failing to comply in CocaCola, exercised significant control over locals in his region, which covered an entire state. ${ }^{30}$

Practical and policy considerations thus militate in favor of some form of functional test. ${ }^{31} \mathrm{~A}$ constitutional standard does provide one method of limiting a much criticized statute. ${ }^{32}$ Yet it is thoroughly inconsistent with the unequivocal intent of Congress which the Supreme Court upheld in American Communications Ass'n v. Douds. ${ }^{33}$ But because the functional test poses substantial difficulties of administration for both the agency and unions, ${ }^{34}$ it should be channeled to meet the demands of daily usage.

tiation of contracts, and even in the handling of grievances. His direct contact with the district and local officers and with influential members gives him an opportunity to present the viewpoint of the central office and even carry out some purely political assignments. ... In a certain sense he is the eyes and ears of the International who can apprise the central office of the desires and fears of the local and district officers and local leaders. The international representative helps to transmit the viewpoint of the central organization to the membership and in turn informs the international officers of the attitudes prevailing in the field. He is the contact between the international and the regional and local leadership and upon his advice and influence may depend not only the progress of the membership and the efficiency of the union, but also the political tranquility of the whole organization. ..."

TAFt, The Structure and Government of Labor Unions 240-41 (1954).

For illustrations of organizers' duties, see constitutions of the International Union of United Brewery Workers (1954) and the United Furniture Workers of America (1952), on file in the Industrial Relations Section of the Princeton University Library.

30. Compare Brief for Respondent, pp. 55-61 and Brief for Respondent in Reply to Amicus Curiae Brief, pp. 5-7, with Brief for $\mathrm{CIO}$ and AFL as Amicus Curiae, pp. 4-9, NLRB v. Coca-Cola Bottling Co. of Louisville, 350 U.S. 264 (1956).

31. Rule X-3B-2 of the Securities Exchange Commission embodies a functional officer test to determine whether an individual is to be liable for "insider profits" pursuant to the Securities Exchange Act of 1934, § 16(b), 48 STAT. 881, 15 U.S.C. \$ 78p(b) (1952). The rule provides:

"The term 'officer' means a president, vice-president, treasurer, secretary, comptroller, and any other person who performs for an issuer, whether incorporated or unincorporated, functions corresponding to those performed by the foregoing officers."

While this definition has been subjected to varying interpretations, its main character remains unaltered: "officer" status is ascertained by functions determined in a factual inquiry, not by labels. See Exchange Act Release No. 2687, Nov. 16, 1940; Colby v. Klune, 178 F.2d 872 (2d Cir. 1949) ; Lockheed Aircraft Corp. v. Rathman, 106 F. Supp. 810 (S.D. Cal. 1952) ; Lockheed Aircraft Corp. v. Campbell, 110 F. Supp. 282 (S.D. Cal. 1953).

32. See American Communications Ass'n, CIO v. Douds, 339 U.S. 382, 415 (concurring opinion of Frankfurter, J.) (1950); $i d$. at 422 (concurring, dissenting opinion of Jackson, J.) ; id. at 445 (dissenting opinion of Black, J.); Comment, The Non-Communist Affidavit Requirement of the Taft-Hartley Act, 18 U. CEI. L. REV. 783 (1951); 51 CoLUM. L. REv. 130 (1951).

33. 339 U.S. 382 (1950); see note 1 supra.

34. This problem has been recognized by both the Supreme Court and the Board. See NLRB v. Coca-Cola Bottling Co. of Louisville, 350 U.S. 264, 266 (1956); Coca-Cola Bottling Co. of Louisville, 108 N.L.R.B. 490 (1954). The Board talks of the burden on 
The wide scope of the functional test presents three problems of administration. The first is one of proof: whether evidence of an individual's duties and functions warrants the conclusion that he is actually an officer for purposes of section $9(\mathrm{~h})$. It is unlikely any all-inclusive yet meaningful standard of proof can be formulated to overcome this obstacle. As individual cases come before the Board, the accumulation of experience will result in greater specificity. Although each case will turn largely on its own facts, some general standards seem relevant. Distinctions should be made among the different levels of labor organization. For example, a challenged individual's position as a nonconstitutional executive at the international or federation level should always be open to inquiry because of the breadth of influence these organizations generally exercise. $^{35}$ Nonconstitutional posts at the local level should be scrutinized from the standpoint of the local's relative independence from control by the parent bodies in such important areas as collective bargaining and organizing. ${ }^{36}$ At all levels, the investigation should focus on the discretionary nature of the individual's duties and his responsibility for results.

The imprecise nature of the functional test creates a second difficulty : unions will be confronted with uncertainty in deciding who must file when they comply initially. Under the test, labor organizations could inadvertently lose compliance status if an individual who has not filed is later adjudged an officer in Board proceedings. This problem can be minimized, however. In unfair labor practice proceedings, the compliance requirement of section $9(\mathrm{~h})$ means that non-Communist affidavits must be on file with the Board before the agency issues a complaint on the charging union's behalf. The section does not prevent a noncomplying union from filing an unfair labor practice charge, the action

administrative efficiency if a test other than its constitutional test were employed. See also Letter from Russell R. Miller to Harold Cranefield, April 3, 1956, Brief for Local 833, UAW, on Review of Intermediate Order, Kohler Co., No. 13-Ca-1780, Nov. 9, 1956.

35. See note 36 infra.

36. While the power of labor federations such as the CIO and AFL has continued to be extensive, see Peterson 41-42, and Barbash, The Practice of Unionism 45-48, 5055 (1956), independent internationals have in recent years increased their power vis-à-vis local unions. Reflecting centralization of control, matters such as collective bargaining increasingly are handled by the international because of the growing need for industrywide bargaining and because local officers fear rank and file criticism for entering into contracts and agreements which fail to conform to local employee demands. See Shister, Who Controls Union Policies, Yale Untversity Labor and Manageanent Center, RePRINT No. 8 (1947) ; Pierson, The Government of Trade Unions, 1 IND. AND LAB. REL. Rev. 593, 604-06 (1946) ; Shister, Union Control in Collective Bargaining, 60 Q.J. EcoN. 513 (1946). BARBASH, op. cit. supra at 57-58. The relative autonomy of local unions differs from industry to industry. The construction industry, for example, conducts bargaining substantially on a local level because of a lack of effective nationwide employer organization. Pierson, supra at 605; PETERson 58-59. The Printing Trades and Teamsters Unions also generally bargain locally. BARBASH, op. cit. supra at 58 . And different types of work conducted by locals within an international's jurisdiction may result in certain locals conducting their own bargaining. See discussion of International Ladies' Garment Workers Union, supra note 25. 
which tolls the statute's six-month period of limitations. ${ }^{37}$ If compliance is found lacking after functional test litigation, the union could then comply and have a new complaint issued based on the original charge. ${ }^{38}$ To minimize delay, this complaint could then be given hearing priority. ${ }^{30}$ In representation proceedings, a petitioning union should be permitted to comply if subsequent litigation shows that one of its officers has failed to file. ${ }^{40}$ In such cases, the original representation petition need not be invalidated; under present practice the Board permits petitioning unions, whose compliance has "lapsed" after the representation hearing, to secure a ballot position conditioned on renewal of compliance within two weeks after the election is ordered. ${ }^{41}$ This approach could be applied to similar lapses determined after functional test litigation. Current Board practice may also furnish the solution for unions allowed to intervene in a representation proceeding. If found not to be in compliance, such

37. See $\$ 9(\mathrm{~h})$, cited note 1 supra; NLRB v. Dant, 344 U.S. 375 (1953).

Section 10(b), 61 Stat. 146 (1947), 29 U.S.C. $\$ 160$ (b) (1952), provides:

"[N]o complaint shall issue based upon any unfair labor practice occurring more than six months prior to the filing of the charge with the Board. . . "

38. NLRB v. National Container Corp., 211 F.2d 525, 536-37 (2d Cir. 1954) ; NLRB v. Kobritz, 201 F.2d 156, 157 (1st Cir. 1953) (dictum). An amended complaint is insufficient, however. NLRB v. Atlanta Metallic Casket Co., 205 F.2d 931, 936 (5th Cir. 1953). Cf. Shell Chemical Corp., 108 N.L.R.B. 284 (1954); 19 NLRB ANn. Rep. 15-16 (1954).

39. The General Counsel could refuse to issue the new complaint if the original noncompliance by the challenged individual resulted from the union's "bad faith." Bad faith noncompliance may be evidenced by alteration of a constitution to remove an office in name only, control through figurehead officers, or the dropping of an officer to an insignificant position without a relinquishment of his power and influence. Pursuant to its Rules and Regulations, $\$ 102.13$ (Series 5, 1948, as amended in 1950), and $\S 102.13$ (b) (3) (Series 6, 1952), the Board has conducted compliance investigations in such situations. Compliance Status of Local No. 1150, UE, 96 N.L.R.B. 1029 (1952) (whether trustees were to be designated as officers); Grower-Shipper Vegetable Ass'n, Case No. 21-RC-1231 (1950), reported in 15 NLRB ANN. REP. 21 (1950) (no concealment of officers); Columbia Broadcasting System, Inc., Case No. 2-UA-5588 (1950), reported in ibid. (same); Alaska Salmon Industry, Inc., Case No. 19-RC-327 (1950), reported in ibid. (former president who assumed another position required to file affidavit). Some investigations resulted in revocation of compliance status. Compliance Status of Furniture Workers, Local 576, 107 N.L.R.B. 872 (1954) (constitution altered to omit certain positions); Compliance Status of United Electrical Workers, Local 1421, 107 N.L.R.B. 147 (1953) (trustees held officers); Sunbeam Corp., 98 N.L.R.B. 525 (1952) (trustees held officers).

40. Alaska Salmon Industry, Inc., (Case No. 19-RC-327, unreported) in 15 NLRB AnN. Rep. 21 (1950) supports this view although the case involved the noncompliance of an intervening union. Seeking a ballot position in a representation election, the union was ruled in compliance after the Board requested an additional affidavit from an officer.

41. Black, Sivalls \& Bryon, Inc., 89 N.L.R.B. 257 (1950); The Fuller Automobile Co., 88 N.L.R.B. 1452 (1950); Milk Products Manufacturers' Ass'n, 88 N.L.R.B. 317 (1950) ; Plywood-Plastics Corp., 85 N.L.R.B. 265 (1949). See 15 NLRB ANn. Rep. 26 (1950). See also Tube Turns, Inc., 101 N.L.R.B. 528 (1952) ("lapse in compliance" immediately before and after a representation election invalidates election but does not require dismissal of representation petition). 
unions, upon a showing of an "adequate interest" in certification, ${ }^{42}$ may participate in the subsequent election by complying with the act.43

A third difficulty in administering the functional test inheres in the right of employers and rival unions to raise noncompliance in unfair labor practice and representation proceedings: the right of "direct litigation."44 In Coca-Cola the Supreme Court affirmed the right of direct litigation while noting the danger

42. "Adequate interest" is represented by employee authorizations, acquired prior to the representation hearing, to have a union serve as bargaining agent. Sylvania Elec. Products, Inc., 87 N.L.R.B. 597 (1949). Authorizations from 30\% of the employees is usually considered adequate. Statements of Procedure of the NLRB $\$ 101.17$ (Series 6, 1952).

43. See Associated Business Serv., 107 N.L.R.B. 219 (1953) ; Sylvania Elec. Products, Inc., 87 N.L.R.B. 597 (1949); 15 NLRB ANN. Rep. 27 (1950).

44. The right stems from the Supreme Court decision in NLRB v. Highland Park Mfg. Co., 341 U.S. 322 (1951). Over Board objections that compliance matters were solely for independent administrative determination not reviewable in the courts, Highland Park allowed an employer to raise compliance issues in an unfair labor practice proceeding. Compliance, the Court stated, affected the Board's jurisdiction to hear a dispute. And the question of whether the organizations involved were required to comply was a reviewable legal issue.

The decision was given varying interpretations. Highland Park held that federations such as the CIO and AFL were "national or international labor organizations" within the meaning of $\S 9(\mathrm{~h})$ and their officers were therefore required to file affidavits. Seizing upon this peculiar factual context, the Board continued to hold that compliance matters could not be disputed in unfair labor practice and representation proceedings. Mason Can Co., 115 N.L.R.B. 105 (1956) ; Cessna Aircraft Co., 114 N.L.R.B. 1191 (1955) ; Coca-Cola Bottling Co. of Louisville, 108 N.L.R.B. 490 (1954). The agency thus interpreted Highland Park to determine only whether these organizations were required to comply. CocaCola Bottling Co. of Louisville, supra at 491 n.4; 16 NLRB ANN. REP. 42,47 (1951). It felt that the grant of review did not necessarily require a right of direct litigation. CocaCola Bottling Co. of Louisville, supra at 492 n.14.

Federal courts have viewed Highland Park as upholding an adverse party's right to litigate compliance matters. Goodman Mfg. Co. v. NLRB, 227 F.2d 465 (7th Cir. 1955), dismissed by consent, 351 U.S. 901 (1956), apinion withdrawn, judgment aff'd on new opinion, 234 F.2d 775 (7th Cir.), cert. denied, 352 U.S. 872 (1956); NLRB v. Coca-Cola Bottling Co. of Louisville, 219 F.2d 441 (6th Cir. 1955), rev'd on other grounds, 350 U.S. 264 (1956) ; NLRB v. Clark Shoe Co., 189 F.2d 731 (1st Cir. 1951). The courts followed, however, a distinction made in Highland Park between the statutory obligation of labor organizations' officers to comply and the factual issue of whether a specific officer admittedly required to comply had in fact filed an affidavit. The former, "necessity of compliance," was litigable; the latter, "fact of compliance," was not. See Goodman Mfg. Co. v. NLRB, supra; Law v. NLRB, 192 F.2d 236 (10th Cir. 1951); NLRB v. Clark Shoe Co., supra; NLRB v. Wiltse, 188 F.2d 917 (6th Cir.), cert. denied, 342 U.S. 859 (1951). Confusion and loose terminology have in general marked this "necessity-fact" distinction. See NLRB v. Sharples Chemicals, Inc., 209 F.2d 645 (6th Cir. 1954). The veracity of the affidavits is another matter that cannot be litigated by adverse parties, see, e.g., NLRB v. Eastern Mass. St. Ry., 235 F.2d 700 (1st Cir. 1956) ; NLRB v. Vulcan Furniture Mfg. Corp., 214 F.2d 369 (5th Cir. 1954), or even questioned by the Board, Leedom v. International Union of Mine Workers, 352 U.S. 145 (1956) ; Amalgamated Meat Cutters Workmen v.NLRB, 352 U.S. 153 (1956). 
that its exercise would delay the main proceedings. ${ }^{45}$ Although the mechanical constitutional test adopted by the Court in that case reduces such delays, it does so by ignoring legislative intent. ${ }^{40} \mathrm{~A}$ more appropriate solution would seem, therefore, to be either a rejection of the right to raise noncompliance in such proceedings or a frank subordination of administrative convenience to the purposes of the act.

Arguments against the right of direct litigation emphasize the delay inherent in the adjudication of issues collateral to those for which the administrative proceeding is held. ${ }^{47}$ In addition, since the NLRB alone has the expertise needed to cope with labor problems, ${ }^{48}$ it might be contended that compliance should be left to the Board's determination in independent proceedings directed to the sole purpose of investigating compliance status. ${ }^{49} \mathrm{~A}$ third argument would stress the opportunity direct litigation gives employers and rival unions to raise frivolous contentions either for the purpose of delay or in order

45. 350 U.S. at 267-68. The Court rejected the Board's view and adopted that of the federal courts. See note 44 supra.

In spite of the decision, disagreement still continues. The Board has not abandoned its hostility to the right of direct litigation. In a series of recent decisions the Board declared litigation permissible only on "interpretation of the statutory language" of $\S 9(\mathrm{~h})$. E.g., Desaulniers and Co., 115 N.L.R.B. 1025 (1956) ; California Furniture Shops, Ltd., 115 N.L.R.B. 1399 (1956) ; Crenshaw's, Inc., 115 N.L.R.B. 1374 (1956). By this language the agency apparently intended to bar direct litigation of whether an individual was an officer of the union even under the constitutional test. See Brief for the General Counsel on Review of Intermediate Order, pp. 2-4, Kohler Co., No. 13-Ca-1780, Nov. 8, 1956.

The First Circuit has interpreted Coca-Cola as abolishing the distinction between necessity and fact of compliance entirely. In NLRB v. Puerto Rico Food Products Corp., 232 F.2d 515 (1st Cir. 1956), the court recognized a right to litigate questions of whether affidavits by individuals admittedly required to comply have actually been filed. A preferable interpretation would be that the Supreme Court did not reject the distinction entirely but rather only the Board's restrictive view of what that distinction was. See NLRB v. Coca-Cola Bottling Co. of Louisville, 350 U.S. 264, 267 (1956); Brief for Petitioner, pp. 46-48, NLRB v. Coca-Cola Bottling Co. of Louisville, supra. While appearing to broaden the scope of compliance litigation, the First Circuit's decision will probably make few changes in present practice. The Board will not rule the union in compliance unless all required affidavits have been submitted and will supply this filing information to parties in interest prior to any proceeding. Sunbeam Corp., 94 N.L.R.B. 844 (1951).

46. See notes 20 and 21 supra and accompanying text. Se'e also text at note 33 supra.

47. See NLRB v. Coca-Cola Bottling Co. of Louisville, 350 U.S. 264, 268 (1956); Coca-Cola Bottling Co. of Louisville, 108 N.L.R.B. 490 (1954); Lion Oil Co., 76 N.L.R.B. 565 (1948) ; 19 NLRB ANN. REp. 10 (1954).

48. NLRE v. Coca-Cola Bottling Co. of Louisville, 350 U.S. 264, 269 (1956) ; NLRB v. Highland Park Mfg. Co., 341 U.S. 322, 327 (1951) (dissenting opinion of Frankfurter, J.) ; $i d$. at 327-2S (dissenting opinion of Douglas, J.) ; Universal Camera Corp. v. NLRB, 340 U.S. 474, 488 (1951) ; NLRB v. Hearst Publications, Inc., 322 U.S. 11., 130 (1944).

49. The Board has consistently sought to maintain this point of view. See, e.g., CocaCola Bottling Co. of Louisville, 108 N.L.R.B. 490 (1954) (unfair labor practice proceeding); Metropolitan Life Ins. Co., 86 N.L.R.B. 428 (1949) (representation proceeding); cf. Lion Oil Co., 76 N.L.R.B. 565 (1948) (representation proceeding). See also 19 NLRB ANN. Rep. 10 (1954); 16 id. 47 (1951); 15 id. 19 (1950); 14 id. 15 (1949); 13 id. 24 (1948). 
to avoid a decision on the merits of the case. In favor of the right of direct litigation is the contention that adverse litigants, although motivated by selfinterest, ${ }^{50}$ serve to further the purposes of the act by supplementing the supervisory role of an already over-burdened Board. ${ }^{51}$ As a matter of statutory construction, it may also be argued that compliance is a prerequisite to the Board's jurisdiction in representation and unfair labor practice proceedings and may consequently be raised by any party. ${ }^{52}$

Coca-Cola's recognition of the right of direct litigation may be criticized or supported for the reasons stated above, but the existence of such a right is not inconsistent with a functional test. Although, as a dictum in the decision suggests, the right of direct litigation subordinates administrative convenience to the policy of section $9(\mathrm{~h}),{ }^{53}$ the test can be so administered as to work a minimum of delay. In the first instance, the number of claims would be greatly reduced were the Board to adhere to a functional test in its initial administrative determinations on compliance. Allegations of noncompliance should be specified at the beginning of the proceedings; if employers or rival unions fail to claim noncompliance seasonably, they should be deemed to have waived any objections. ${ }^{54}$ Compliance matters should be litigated first and if noncompliance

50. If an individual officer refuses to file, an employer may escape liability for an unfair labor practice or a rival may secure the noncomplying union's elimination from the representation election. See notes 3-5 sipra and accompanying text.

51. Because of a large caseload, the Board amended its rules in 1954 to reduce the scope of its jurisdiction. See Breeding Transfer Co., 110 N.L.R.B. 493 (1954), particular$1 y$ at 497 .

52. Compliance matters were held to be jurisdictional in NLRB v. Highland Park Mfg. Co., 341 U.S. 322 (1951). Despite this decision the Sixth Circuit has at times refused to so view them. It has maintained that failure to comply would only revoke a union's standing before the Board and act as a bar to the proceedings as does the statute of limitations. NLRB v. Sharples Chemicals, Inc., 209 F.2d 645, 650 (6th Cir. 1954) ; NLRB v. Wiltse, 188 F.2d 917, 921 (6th Cir.), cert. denied, 342 U.S. 859 (1951). While the basis for this rationale came from a pre-Highland Park Fourth Circuit decision, NLRB v. Greensboro Coca-Cola Bottling Co., 180 F.2d 840, 845 (4th Cir. 1950), the Sixth Circuit in Sharples, supra, apparently overlooked its own earlier decision in which it labelled compliance jurisdictional. NLRB v. Alside, Inc., 192 F.2d 678 (6th Cir. 1951). Eut for the most part, Highland Park's jurisdictional meaning is recognized. See Goodman Mfg. Co. v. NLRB, 234 F.2d 775, 776 (7th Cir.), cert. denied, 352 U.S. 872 (1956); NLRB v. Atlanta Metallic Casket Co., 205 F.2d 931, 934, 937 (5th Cir. 1953) ; NLRB v. Happ Bros. Co., 196 F.2d 195, 197 (5th Cir. 1952). See also NLRB v. Coca-Cola Bottling Co. of Louisville, 350 U.S. 264, 266 (1956) ; NLRB v. Dant, 344 U.S. 375, 379 (1953).

53. 350 U.S. at 268.

54. The Board, in determining the procedure to be followed during its hearings, can specify that compliance matters be raised initially. See $\$ 6,61$ Stat. 140 (1947), 29 U.S.C. $\$ 156$ (1952). Cf. Administrative Procedure Act, 60 STAт. 237 (1946), 5 U.S.C. $\$ \$ 1001-11$ (1952); $\$ \$ 1001(\mathrm{e})$ and $1002(\mathrm{a})$ recognize an agency's province to determine its proceidural rules.

However, since compliance has been adjudged a jurisdictional matter, see note 52 stipra, a reviewing court might refuse to uphold a waiver of the issue. Such a result seems unlikely; in practice, courts have not treated compliance in a strict jurisdictional sense. Courts have found a waiver by relying on $\$ 10(e), 61$ STAт. 147 (1947), 29 U.S.C. $\$ 160$ (e) 
is shown, the affected union should be denied access to the Board's processes - only if it refuses the opportunity to comply. ${ }^{55}$ In addition to requiring detailed allegations of noncompliance, trial examiners could impose strict criteria of relevancy and materiality of proof at the hearing. Although these recommendations would not eliminate inconvenience, they would minimize the possibilities of abuse while permitting a standard of litigation that more closely conforms to the purposes of section $9(\mathrm{~h})$.

(1952), which prevents the entering of additional evidence before a court of appeals absent a showing of reasonable grounds for failure to litigate the matter before the Board. See NLRB v. Vulcan Forging Co., 188 F.2d 927 (6th Cir. 1951) (leave to admit additional evidence of noncompliance denied for failure to raise issue before Board even though Board could not then have passed on the issue); cf. NLRB v. Shedd-Brown Mfg. Co., 213 F.2d $163,165-67$ (7th Cir. 1954).

If a motion to dismiss a proceeding is denied either on the merits or for failure to raise a timely objection, the litigant has no right to appeal the issue to the Board immediately. Such an appeal can be taken only upon the Board's special permission. Rules and Regulations of the NLRB, $\$ 102.26$ (unfair labor practice proceeding), $\$ 102.57$ (c) (representation proceeding) (Series 6,1956 ). But if a motion to dismiss is granted, Board review can be obtained pursuant to $\$ 102.27$ (unfair labor practice complaint) or $\$ 102.57$ (a) (representation petition).

No interlocutory appeal to the circuit courts is available in any of the above situations. But if the Board dismisses a complaint in whole or in part, the determination is considered a final administrative order under $\$ 10$ (f), 61 SтAт. 148 (1947), 29 U.S.C. $\$ 156$ (1952); Manhattan Constr. Co. v. NLRB, 198 F.2d 320, 321 (10th Cir. 1952) ; Laundry Workers' Union v. NLRB, 197 F.2d 701, 703 (5th Cir. 1952) ; Lincourt v. NLRB, 170 F.2d 306, 307 (1st Cir. 1948). See also Administrative Procedure Act, supra, $\$ 1001$ (d), 1009 (c).

55. See notes 37-43 supra and accompanying text. 